American Journal of Economics and Business Administration 1 (4): 313-319, 2009

ISSN 1945-5488

(C) 2009 Science Publications

\title{
Analysis of Article 27(3) (b) of TRIPs-the Content and Implications of the IP Protection on Plant Varieties
}

\author{
Pratyush Jhunjhunwala \\ WB National University of Juridical Sciences, \\ 12 LB Block, Sector-III, Salt Lake City, Kolkata-70026, India
}

\begin{abstract}
Problem statement: Introduction of Intellectual Property Protection (IPP) to plant varieties has gone through some rough weather with objections being made not only with respect to their introduction but also with the type of protection to be accorded to the new varieties. Article 27(3)(b) of the TRIPs Agreement contains a lot of flexibilities as it allows WTO member states to choose the form of intellectual property protection and also the strength of IP protection. However, one of the primary effects of the provision is that it has forced a good number of the nations across the world to accord IPP to plant varieties where there existed none. The primary rationale given for the introduction of IPP in biotechnology is that it shall incentivise research in biotechnology which in turn shall help nations in building its food security. Conclusion: The study seeks to show that though the rationale has stood true to a good extent (as a lot of new plant varieties have been created by plant breeders in the past few decades that carry special traits resulting in an increase in the agricultural output and the quality of the produce). However, the research in plant varieties is often restricted to only a few crops that are commercially the most viable, hence, showing no change in the pattern of investment in the plant varieties even after the introduction of IPP. Moreover, after the introduction of Article 27(3) (b) (according of IPP to plant varieties and limiting the scope of imitation) there has seen large scale concentration and restructuring of the seeds industry all across the world. Further, the gradual substitution of traditional varieties by the modified plant varieties has also surfaced a whole host of other economic and environmental problems. These problems and holes in the incentive rationale thus justifies the counter measures taken by many nations such as farmer's rights, origin disclosure requirements, incentivizing the use of traditional varieties by farmers, creation of seed's banks, free exchange of germplasm.
\end{abstract}

Key words: Plant variety protection, food security, farmer's rights, gene erosion

\section{INTRODUCTION}

Traditionally, Plant Variety (PV) Management excluded intellectual property rights as the agricultural sector contributes to the fulfilment of basic human needs and it was unacceptable that the system of development of new plant varieties be based on a system that allows individual appropriation of the same ${ }^{[1]}$. However, this policy started changing slowly in the early parts of the twentieth century in the United States and some of the European Countries where agriculture became economically less important and the governments started withdrawing from activities relating to development and supply of seeds to farmers. This withdrawal resulted in an increase in the role private sector in the seeds industry. However, the expansion was being stalled by the very nature of the seeds as the farmers would save, re-sow, sell and exchange seeds saved from the produce. Further, even measures such as entering into agreements with customers to reproduce or offer for sale their varieties proved futile ${ }^{[2]}$. These developments led to the need for providing legal protection to the private sector for ensuring returns on their investments and also to incentivize further investment by the private sector in agricultural sector.

Patents were one of the first forms of intellectual property protection that was accorded in this field. Plants Patent Act of 1930 (PPA), enacted in the United States, gave the plant breeder a patent on all asexually produced plants ${ }^{[3]}$, save tuber-bearing plant, that met the requirements of novelty, distinctness and non obviousness. However, there were several oppositions to the patent paradigm. Firstly, introduction of patents to life forms; secondly, seeds had always been a part of the common heritage of mankind and have been freely exchanged by the farming community for generations. Further, the farming community were regarded as the 
original donors of the seeds or the variety which has merely been improved by the plant breeder. The third objection comes from the advocates of patents who opined that granting patents for plant varieties would lead to the dilution of concept of inventiveness, which is one of the fundamental rationales for granting of a patent as a new plant variety is seen more as an improvement rather than a new scientific invention (Granting of patents to plant varieties even received a lot of support from some eminent personalities such as Thomas Edison who rated plant breeders parallel to mechanical and chemical inventors. See generally, Hearings of H.R. 11372. Before the House Comm. on Patents, 71st Cong. 3 (1930)). Further, the PPA itself had certain limitations as it did not include plants that could be produced through pollination, which then accounted for most new varieties and had very rigid and formal prerequisites that frustrated the incentives for even the eligible plant breeders.

The result of the push for according intellectual property protection to new plant varieties and the opposition to the patent paradigm was the development of a hybrid form of intellectual property right known as the Plant Breeders Rights (PBR). One of the earliest and most significant international treaties on PBR is the International Convention for the Protection of New Varieties of plants (also known as the UPOV Convention) signed on December 2nd, 1961, in Paris, by 8 European countries. The treaty has been revised several times, in particular in 1978 and 1991. United States too had enacted the Plant Variety Protection Act in 1970 (PVPA) to confer intellectual property rights, similar to those of patents, to sexually produced new varieties of plants (US eventually became a signatory to UPOV in 1981. It has also become a signatory to the 1991 revision of the UPOV Convention (UPOV 1991) and has made the necessary amendments to PVPA ${ }^{[14]}$.

Trips: Negotiations: In the TRIPs Negotiations, there primarily existed a North-South divide ${ }^{[4]}$; the developed countries such as United States, most of the European Countries, Japan, Switzerland, forming one block that wanted a stronger Intellectual Property (IP) Regime, whereas the developing countries especially, India and Brazil advocated for weaker a IP Regime ${ }^{[5]}$ as they had more economic advantage in imitation than innovation (this is a holistic representation of the negotiations. EC, Japan, Switzerland and US had each submitted separate drafts during the several rounds of the negotiations stressing on their areas of interest, but at the same time the intension of each of these major participants was to create a strong, enforceable International IP Regime) ${ }^{[6]}$. However, the negotiations pertaining to providing a patent regime for living organisms saw the European Community switch sides and advocating against a patent regime for plant varieties (EU was in support of providing IP Protection to plant varieties but not through patents) ${ }^{[7]}$.

The heavily bracketed provision of the Anell Draft Text (W/76), which was under negotiations in July 1990 showed how the different views and interests of the parties were. The text alluded to the possible exclusion from patentability of:

\section{"1.4.4 [Any] plant or animal [including micro- organisms] [varieties] or [essentially biological] processes for the production of plants or animals; [this does not apply to microbiological processes or the products thereof]. [As regards biotechnological inventions, further limitations should be allowed under national law]"}

The differences between the participating countries continued even during the Brussels negations, of December, 1990. The Brussels Text allowed the parties to exclude from patentability:

"[(b) Animal varieties [and other animal inventions] and essentially biological processes for the production of animals, other than microbiological processes or the products thereof. PARTIES shall provide for the protection of plant varieties either by patents or by an effective sui generis system or by any combination thereof. This provision shall be reviewed [... ] years after the entry into force of this Agreement.]

[b) B. Plants and animals, including microorganisms and parts thereof and processes for their production. As regards biotechnological inventions, further limitations should be allowed under national law.]"

Article 27 (3) (b) of the TRIPs agreement: The TRIPS negotiations were concluded in December, 1993 and the TRIPS text was formally adopted at Marrakesh, Morocco in April, 1994. Article 27 (3) (b) of the Agreement provides for mandatory intellectual property rights on plant varieties. The Article is as follows:

'Article 27: Patentable subject matter:

Members may also exclude from patentability: (b) Plants and animals other than micro-organisms and essentially biological processes for the production of plants or animals other than non-biological and 
microbiological processes. However, Members shall provide for the protection of plant varieties either by patents or by an effective sui generis system or by any combination thereof. The provisions of this subparagraph shall be reviewed four years after the date of entry into force of the WTO Agreement'.

A bare reading of the above provision raises three primary issues:

- Exclusion of plants and biological processes for their creation from patentability but protecting plant varieties

- Protection that is to be provided by the members shall be provided by either patents or an effective sui generis system or a combination thereof

- Review of the said provision after four years of entry into force of the WTO Agreement

Exclusion of plants but protection to plant varieties: The sub-Article allows members to exclude plants and biological processes for their creation from patentability; however, protection must be extended to plant varieties (and to micro-organisms and any nonbiological process). The provision neither defines the term plant variety nor does it clarify the difference between a plant and a plant variety. UPOV 1991 defines the term "plant variety" as "a plant grouping within a single botanical taxon of the lowest rank, which grouping, irrespective of whether the conditions for the grant of a breeder's right are fully met, can be defined by the expression of the characteristics resulting from a given genotype or combination of genotypes, distinguished from any other plant grouping by the expression of at least one of the said characteristics and considered as a unit with regard to its suitability for being propagated unchanged".

From the above definition it can be understood that the term plant variety may refer to a grouping of plants genetically created that has at least one genetic characteristic different from a pre-existing grouping and must be transgenic in nature. Again however, there is no indication of any definition of the term in the TRIPs Agreement giving members the flexibility to further narrow down the scope of the term plant variety and create more stringent conditions that a variety must meet to be given protection.

Patents or effective sui generis system or a combination thereof: The sub-Article makes it mandatory to protect plant varieties through either patents or an effective sui generis system or a combination thereof. This indicates that a number of countries rejected the compulsory introduction of plant patents and that there was no consensus on an alternative IP protection regime. Further, what would constitute as an effective sui generis system has not been defined in the Agreement. This is regarded as one of the many flexibilities in the Agreement as it allows the members to decide the level of requirement for acquiring an IPR on the plant variety and the extent of the same. One of the explanations can be that the context in which the term has been employed in TRIPs implies that the member state must provide a mechanism of enforcement of rights and procedures for the multilateral prevention and settlement of disputes, in which rights to be conferred by an IPR are either defined in detail, or as "equitable remuneration ${ }^{[8] "}$. Again however, the limitation of this approach is that it interprets the term effectiveness merely in terms of the rights and remedies available to the IPR holder upon infringement and does not take into consideration the requirements for acquiring the right or the level of protection that shall be accorded to the right holder. One of the agreed interpretations is that UPOV is an effective sui generis protection regime as mandated by TRIPs Agreement (legal implications discussed below). Though the provision may contain certain flexibilities one of the implications of the provision is that members who prior to TRIPs did not provide any intellectual protection to plant varieties, micro-organisms and nonbiological processes for the creation of plants, animals, will now have to compulsorily provide intellectual property protection.

Revision of the article 27 (3) (b): The controversial nature of the obligations under Article 27(3)(b) led to a consensus of review of the provision by the members in 1999, four years after the enforcement of the WTO Agreement ${ }^{[9]}$ and the said provision is the only provision in the entire TRIPs text to have a revision clause. The TRIPs Council commenced review in late 1998, but the negotiations were transferred to the General Council as the members prepared for the Seattle Ministerial Conference to be held in December 1999. During the two meetings, the Developing Countries demanded that amendments be made to TRIPs agreement to harmonize all conflicts that existed between the TRIPs text and other international agreements and conventions such as the Convention on Biodiversity, International Undertaking on Plant Genetic Resources, introduction of origin disclosure requirements, benefit sharing, farmer's rights and introduction of more exemptions into the text of the Agreement. The Developed countries rejected the existence of any discrepancies between the obligations under TRIPs and other International Agreements and 
sought to raise the standards of protection under TRIPs. No agreement could be reached at the Seattle Conference as there was a dead-lock between the two sides. Attempts were also made at the Doha and Cancun Ministerial Conferences but to no avail.

Hence, on the whole Article 27(3)(b) of the TRIPs Agreement is a very flexible provision as allows members to differently interpret terms plant varieties and efficient sui generis system and thereby affix their own requirement and protection standards. However, the provision has made IP protection to plant varieties mandatory, compelling nations to make laws and enforcement agencies protecting the rights of plant breeders where there none prior to TRIPs.

Implications of IP rights in PV, focusing on article 27(3)(b): The implications of Article 27(3) (b) of the TRIPs Agreement which is binding on all members of WTO, shall be discussed under the following heads:

- Legal and policy changes

- Economic implications

- Impact on environment

\section{Legal and policy changes:}

Mandatory protection: The foremost implication of Article 27(3) (b) of the TRIPs Agreement is that it has compelled a large number of countries to change their stance on IP protection on PVs and mandatorily enact and enforce legislations, where there were none before, to provide IP protection to PV from 1999 onwards. Though there are flexibilities that enables a member country to determine terms "plant variety" and "effective sui generis system" in ways that allows them to dilute the level of protection, however, they cannot escape from providing protection completely. Another important point concerning the Article 27(3) (b) is that the provision must be read in a manner such that it does not run counter to any other International obligation that a country may have, such as the obligation to protect and enhance biodiversity under Article 8(j) of the Convention on Biodiversity, 1992. Members may use provisions of CBD such as Articles 8, 15, 16 and require an applicant for IP on PV to disclose the country of origin, ensure benefit sharing and even use the restrict access clause to prevent appropriation of its biodiversity by foreigners. Having such provisions in its laws cannot be said to be in violation to TRIPs as the said Agreement does not prohibit any of the above. However, WTO members may be forced to have TRIPs-plus provisions as a part of their obligation under some other International Agreement or Arrangement, thereby nullifying the effect of the flexibilities in TRIPs.
Increase in UPOV's membership: As mentioned earlier, no definition or explanation has been given of the term "effective sui generis system", however, the protection that is provided under UPOV has been regarded by the Secretariats of both WTO and UPOV as the only internationally recognized effective sui generis system for the protection of plant varieties. But this does not preclude nations to develop their own protection system (India is one of the many countries that is not a signatory to UPOV and has enacted Protection of Plant Varieties and Famers Rights Act, in 2001 to comply with its TRIPs obligation. The law has so far not been challenged as a non-effective sui generis protection system by any nation). Again, however, many countries which did not have the adequate knowledge for creating a protection system that would best suit their interest and at the same time fulfil their obligations under TRIPs have become or have committed to becoming signatories to UPOV, thereby accepted UPOV 1991, which is a much stronger protection mechanism than UPOV 78 , as the protection mechanism for plant varieties (one of the most prominent examples of this is the Agreement to revise the Bangui Agreement on the Creation of an African Intellectual Property Agreement and to model it on UPOV 1991). Further, countries have joined UPOV and adopted UPOV 1991, as a part of their obligation under certain Trade Agreements with developed nations or because of other international arrangements which contain the TRIPs plus provision that requires them to become a signatory to UPOV (examples include the Central American Free Trade Agreement, NAFTA and the free trade agreements: USA-Jordan, EU-Mexico and some Euro-Mediterranean Association Agreements. The Draft of the Free Trade Agreement of the Americas expresses UPOV 1991 as an effective sui generis system. Further, EU is a signatory to UPOV 1991, thereby compelling all EU members to accept the obligations of UPOV 1991. In 1995, EU adopted the Community Plant Variety Rights, which is in conformity with UPOV 1995.

Concept of farmer's rights: The primary argument in support of according benefits and rights to farmers is to acknowledge their contribution to the biodiversity and for being the original donors of the plant genetic varieties that have been used by plant breeders to create new genetically modified varieties. This is reflected in definition given by the International Undertaking on Plant Genetic Resources and the numerous resolution passed by it on the same. The same has been recognized by International Treaty on Plant Genetic Resources for Food and Agriculture (PGRFA). However, these 


\section{Am. J. of Economics and Business Administration, 1 (4): 313-319, 2009}

International Instruments are not binding and also do not create any property rights for the farmers, however, PGRFA leaves it open for a member nation to create property rights if it wants and also advocates for compensating the farmers for their contributions to the development and maintenance of the agricultural biodiversity. In addition to the above mentioned right under PGFRA, the primary rights that may be given to farmers are: (a) right to save, use, exchange and sell farm saved seeds; (b) right of the farmer to further develop the varieties created by plant breeders; (c) give farmers intellectual property rights over their assets. The Indian law on IP Protection to plant varieties entails an entire chapter that is devoted to the concept of farmer's rights. The Protection of Plant Varieties and Farmer's Rights Act, 2001, strives to protect farmer's rights in two ways: (a) protecting their on farm activities; (b) providing incentives and rewards to farmers for their contributions. Under the second category, the Act through Section 39, gives the farmers the right to save, use, sow, re-sow, exchange, share or sell his farm produce including the seeds of a protected variety, however, what a farmer sell cannot be branded. Further, the Act seeks to reward the farmers for their contributions to the agricultural biodiversity and also provides for disclosure of place of origin by the plant breeder, benefit sharing and research rights. Moreover, the Act also prohibits plant breeder rights on "Terminator Seeds" and also asks for disclosure of the expected performance of the seeds or the planting material to the farmers and compensating them if they fail to perform.

Economic and social implications: The Economic and social implications of Article 27(3) (b) and IPR in plant varieties shall be discussed under the following heads:

Incentives, price and food security: The primary rationale behind increasing the strength of IP protection under TRIPs was to incentivize research in biotechnology. The developed countries had contended that introduction of IP protection in plant varieties will encourage plant breeders to come up with new and better varieties that shall help the country to satisfy its food grain requirement by creating such modified varieties that provide a better yield, are more pest resistant, require less water or the fruit from the plant has more nutrients. Studies have shown that there is indeed a link. In Argentina, after the government had allowed registration and commercialization of GM varieties, there had been a considerable increase in the number of plant variety registrations and the total produce of corn, but there was very little increase in the number of registrations or the produce of soybeans (Corn and Soybeans are two of most harvested crops in Argentina and United States) the primary reason for this was that there exists a strong black market for soybeans in Argentina that has prevented plant breeders from successfully exploiting the developed varieties, showing that a weak protection and enforcement mechanism has dissuaded investment by plant breeders and thereby there has little increase in the total produce of soybean ${ }^{[10]}$. However, similar results have been found in United States and the reason for less investment by the private investment in US is not weak protection for soybean; but the difference in the characteristics of the hybrid varieties of the two plants. Seeds saved from corn hybrids when replanted do not produce reasonable yields whereas the yields from seeds saved from soybean hybrids are nearly as much as that of the previous year ${ }^{[11]}$. Further, the results of comparison between wheat and corn in US after the introduction of IPR in PV show similar results. The US example therefore clearly shows that it is not increasing IP protection is not a perfect solution as research shall be conducted by plant breeders only in those crops that are commercially most profitable to them and not what is most required by the nation to attain the desired level of food security.

After the introduction of IPP in PV there has been an immediate impact in the price of the seeds that are being made available to the farmers and this increase is then reflected in the increase in price of the commodity that is finally being made available to the consumers. In most of the developing countries the local people would have to reduce their consumption of that particular food grain and would have to switch over to cheaper substitutes. This increase in the cost and the subsequent decrease in the consumption of the food grains impose great problems upon the farmers who then resort to various measures to reduce the cost of production. One of the mechanisms of cost reduction that the farmers in Argentina have been compelled to take is to use farm saved seeds of corn hybrids even though the total yield from those varieties is much less. Instances such as those mentioned show large holes in the hypothesis that better IPP will always help a nation reach better levels of food security.

Utility of $\mathrm{PV}$ protection in case of international trade and health concerns: In the last few decades a lot of concerns have been raised over the safety of consuming GMOs and it is for protecting its people from any health concerns that may arise from the consumption of GMOs that many nations have incorporated strict rules for importation of GMOs, such 


\section{Am. J. of Economics and Business Administration, 1 (4): 313-319, 2009}

as members of EU and so providing IP Protection to PV may, instead of facilitating international trade and economic growth, adversely affect a country's interests. A good example of this can be found in Egypt. Potato is one of the most widely grown vegetables in Egypt and country is also one of the largest exporters of potatoes and EU is the largest importer of potatoes grown in Egypt $^{[12]}$. EU even gave Egypt tax exemptions on 190,000 tons of potatoes exported by it and after that the usual rate of $19 \%$ was applicable. The Egyptian potatoes are often infected by PBT pest and this accounts for the destruction of large portions of the total potatoes grown in the nation. Massachusetts State University (MSU) and scientists from Egypt conducted a lot of research and came up with a variety that is resistant to PBT pest. They would have introduced the variety into the local Egyptian markets if adequate IP protection was given. This news received a lot of local attention and the government was agreeable to introduce protection as that would have helped the country to meet food sufficiency problems and would prove to be immensely beneficial. However, EU cautioned Egypt against the introduction of the modified variety of seeds into its markets and making the same available to its farmers as EU has a no GMO import policy and would stop importing potatoes from Egypt as it felt that Egypt did not have the required facilities that would prevent mixing of the modified variety from the traditional one. To further affect Egypt's decision, the cap of tax exemption level was increased to 250,000 tons. This situation had occurred prior to 1994. Now, as per Article 27(3)(b), a country that is met with such a situation would have no way out as the protection mechanism that had stalled the introduction of the PV would no longer be there and Egypt would be in danger of losing out on its largest potato importer. There have also been instances in the past where nations that had faced severe food shortage problems rejected supplies from other countries as the food being supplied were GMOs, e.g., rejection of US aid by Uganda and other African nations as they had a strict no GMO policy.

Concentration of the seed industry: One of the primary reasons for developed countries to lobby for introduction of IPP in PV was to augment the interests of its industries and large corporations. After the formalization of UPOV and TRIPs agreement, which have caused drastic changes in the IPP regime in Agriculture, there has been a rapid increase in the number of acquisitions and mergers, leading to massive concentration and restructuring of seeds industry all across the world, for example Monsanto had alone between 1996-98 had made nearly 18 overseas acquisitions estimating to USD 7.3 Billion, formation of Novartis Ciba, Geigy and Sandoz and Novartis' acquisition of 6 French firms. A careful analysis of the mergers and acquisitions that have taken place post 1991 would show that the transferee or the acquirer company is always a company that is based in a Developed Country and the transferor or the target company belongs to a developing nation.

Impact on environment: Biotechnology has contributed to food security through high-yielding, more pest resistant plants and plants that can survive with fewer water supplies. It has also proved beneficial to the environment through micro-organisms, controlling pollution and waste-water disposal ${ }^{[13]}$. However, releasing genetically engineered plants and animals can severely damage the finely tuned ecosystem and these hazards are unpredictable and irreparable, example, clogging of the African waterways by the South American water hyacinth. As mentioned earlier the varieties sold by the plant breeders have high yield and other special features that cause farmers to often prefer modified varieties over the traditional varieties. The PV seeds that are created and sold by the large plant breeders are often created under particular environmental conditions and are best suited to grow under those conditions only, however, seeds of these plants are sold worldwide and this may intern harm the ecosystem. Further, the modified varieties usually have certain very common genetic traits and yields from the saved seeds are often very low which may often lead to "gene erosion" and "gene uniformity", causing loss of some very important genetic traits and eventually loss of the traditional variety (Examples of these can be the Indian Pearl Millet, traditional Taiwan Rice Strains ${ }^{[10]}$. Further, practices of monocropping causing genetic uniformity create possibilities of epidemics (One of the oldest and the most devastating epidemics resulting from widespread monocropping was the Irish Potato Famine of the $1840 \mathrm{~s}$ that nearly reduced the population of Ireland by one-third ${ }^{[10]}$. This may happen because a particular variety may not be able to resist certain pests and even conditions which the traditional variety would have successfully endured. An example of need and non-availability of traditional variety occurred in Philippines, where the widely used IR-8 strain of rice was hit by Tungro disease, causing the farmers to switch to IR-20, which proved vulnerable to grassy stunt viruses and brown hopper insects. Farmers then moved to a super-hybrid, IR-26. This variety proved to be resistant to almost all local insects and diseases; 
however, it could not withstand strong winds. Plant breeders the decided to use the traditional rice strains of Taiwan as the variety had the unusual ability to withstand powerful, however, the variety had been eliminated as the Taiwanese farmers had switched over to IR-8. Now, Article 27(3) (b) and similar provisions of law that create and strengthen the IPP Regimes for plant varieties, encourage practices that lead to such environmentally devastating results. IPP Regimes primarily focus on according more and more advantages to private plant breeders, whose only interest is maximization of profits and not to protect the environment. There is generally no mechanism that can be created purely through IP Rights to promote and encourage conservation and promotion of the biosphere. Creation of new germplasm and its free exchange may be one of the ways to reduce gene erosion and gene uniformity, however, IP Rights may be misused to the extent of preventing the exchange and transfer of new and traditional germplasm and thereby counter the efforts that are being taken for conservation of the biosphere. The probable solution to the problem may be that the IP laws governing plant varieties should be read in consonance with laws conserving and promoting biodiversity and efforts such as creation and maintenance of "seed bank" should be given importance both at domestic and international levels.

\section{CONCLUSION}

The contributions that biotechnology has made to mankind is quite significant and intellectual property rights are required to act as incentives for plant breeders to indulge in further research and development. However, time and again ill-effects of genetically modified plants as well as strong IPP for plant breeders have surfaced. Article 27(3) (b) of the TRIPs Agreement has made it mandatory for all members of WTO to introduce within their legal regime IP protection for PVs either through patents or an effective sui generis system or a combinations thereof. The Article has certain flexibilities and these flexibilities can be used by members to create an IPP mechanism that is best suited to serve its economic and social interests.

\section{REFERENCES}

1. Cullet, P., 2005. Intellectual Property Protection and Sustainable Development. 1st Edn., LexisNexis Butterworths, ISBN: 81-8038-104-8, pp: 226.
2. Nelson, A., 2005. Is there an international solution to intellectual property protection for plants? Georgia Washington Int. Law Rev., 37: 999. http://findarticles.com/p/articles/mi_qa5433/is_200 501/ai_n21382158/pg_12/

3. Reichman, J.H., 1994. Legal hybrids between the patent and copyright paradigm. Columbia Law Rev., 94: 2466.

4. Hestermeyer, H., 2007. Rights and the WTO: The Case of Patents and Access to Medicines. Oxford University Press, ISBN: 01-9921520-0, pp: 37-39.

5. Watal, J., 2005. Property Protection and Substantial Development. LexisNexis Butterworths, ISBN: 0-19-566170-2, pp: 21-27.

6. Reichman, J., 1989. Intellectual property in international trade: Opportunities and risks of GATT connection. Vanderbilt J. Trans. Law, 22: 770.

7. UNCTAD-ICTSD, 2005. Resource Book on TRIPs and Development. Cambridge University Press, ISBN: 0-52-185044-4, pp: 391.

8. Dhar, B., 2002. Sui Generis Systems of Plant Variety Protection. Quaker United Nations Office, ISBN: 2-9700323-1-7, pp: 7.

9. Helfer, L.R., 2004. Regime shifting: The TRIPs Agreement and the new dynamics of international intellectual property law making. Yale J. Int. Law, 29: 64.

10. Kesan, J., 2007. Insecure Property Rights and Plant Varieties: The Effects on the market for Seeds and on Farmers in Argentina. In: Agriculture and Biotechnology and Intellectual Property: Seeds of Change, Kesan, J.P. (Ed.). CABI Publications, ISBN: 978-1-84593-201-5, pp: 222.

11. Dhar, T., 2007. The Impact of Intellectual Property Rights in Plant and Seeds Industry. In: Agriculture and Biotechnology and Intellectual Property: Seeds of Change, Kesan, J.P. (Ed.). CABI Publications, ISBN: 978-1-84593-201-5, pp: 164.

12. Oehmke, J.E., 2007. Economic Impact Assessment of Intellectual Property Rights Regulations: The Case of Egypt. In: Agriculture and Biotechnology and Intellectual Property: Seeds of Change. Kesan, J.P. (Ed.). CABI Publications, ISBN: 978-1-84593201-5, pp: 289-294.

13. Bosselmann, K., 1996. Plants and politics: The international legal regime concerning biotechnology and biodiversity. Colorado J. Int. Environ. Law Policy, 7: 118-119.

14. Reichman, J.H., 1994. Legal hybrids between the patent and copyright paradigm. Columbia Law Rev., 94: 1004-1007. 